\title{
THE MIDWEST PIPING DOCTRINE: AN EXAMPLE OF THE NEED FOR REAPPRAISAL OF LABOR BOARD DOGMA
}

\author{
JuLIUS GETMAN†
}

$\mathrm{W}$

HEN rival unions vie for employee support, an employer must behave in a neutral fashion. He must treat them alike and may not grant to one union or its members advantages which he withholds from the others. ${ }^{1}$ The National Labor Relations Board has long held that recognizing or negotiating an agreement with one of the rivals is a form of assistance to that union in its campaign for employee support. ${ }^{2}$ However, recognition is a form of assistance which must be given special treatment. The effectuation of employee choice, the interest which gives rise to the employer's duty of neutrality, often requires that a majority union be granted recognition despite the interference which recognition may cause the organizing efforts of its rivals. This is most clearly so when one of the rival unions has been certified by the Board as the majority representative. Similarly, although operation under a collective bargaining agreement may aid an incumbent union to maintain support, it is not feasible to require an employer to withdraw recognition each time a new union comes on the scene.

The Midwest Piping doctrine ${ }^{3}$ is a Board-formulated rule to distin-

$\dagger$ Assistant Professor of Law, Indiana University.

1 National Labor Relations Act § 8(a)(2), 61 Stat. 156 (1947), as amended, 29 U.S.C. $\S \S 151-66$ (1958) (hereinafter cited as the act); NLRB v. Waterman S.S. Corp., 309 U.S. 206 (1940); California Cotton Co-op. Ass'n, 110 N.L.R.B. 1494 (1954). An employer is permitted to state his preference. Rheem Mfg. Co., I14 N.L.R.B. 404 (1955); Sylvania Electric Products, Inc., 106 N.L.R.B. 1210 (1953). But he may not threaten reprisals if the employees reject his opinion or promise benefits if they go along. Superior Engraving Co., 83 N.L.R.B. 215 (1949); Seamprufe Inc., 82 N.L.R.B. 892 (1949).

2 Phelps Dodge Copper Prods. Corp., 63 N.L.R.B. 686 (1945); Elastic Stop Nut Corp., 51 N.L.R.B. 694 (1943), enforced, 142 F.2d 371 (8th Cir. 1944).

3 The name derives from Midwest Piping \& Supply Co., 63 N.L.R.B. 1060 (1945). The employer in that case had been advised by the CIO that it represented a majority of the employees in a unit which had, until that time, been unorganized. The CIO at the same time filed a representation petition with the NLRB. The employer entered into negotiations with the AFL which also claimed to represent a majority. About two months later the AFL presented membership cards to the employer indicating that it did represent a majority and on that basis the AFL and employer concluded a union shop agreement. The CIO filed a petition with the Board claiming a violation of $\S 8(a)(1)$. The Board, in granting the petition, held that the employer's recognition of the AFL was unjustified and that this action, taken in the face of representation proceedings pending before the Board, in effect corrupted those proceedings. 
guish between those situations in which the grant or maintenance of recognition is a violation of the act and those situations in which it is permissible or required. Essentially the doctrine requires an employer to withhold or withdraw recognition when "faced with conflicting claims of two or more rival unions which give rise to a real question concerning representation ...."4

In this formulation of the doctrine, a "question concerning representation" is a term of art derived from section $9(c)(1)$ of the act which provides that the Board may direct an election after a hearing, "if the Board finds upon the record of such hearing that . . . a question of representation exists." In representation proceedings the Board uses the terms "question of representation" and "question concerning representation" interchangeably. 5 Therefore, in every election there has been a prior determination that a question concerning representation exists. ${ }^{6}$

In Midwest Piping cases the adjectives "real" or "genuine" are often added to "question concerning representation." 7 As used by the Board they add nothing to the statutory term. The tests used to determine whether an election is appropriate are the same tests employed to determine the applicability of the Midwest Piping doctrine ${ }^{8}$ and the Board has uniformly applied it whenever a question concerning representation ${ }^{9}$ is

4 Novak Logging Co., 119 N.L.R.B. 1573, 1574 (1958). See also, e.g., North Elec. Co., 129 N.L.R.B. 675, 676 (1960), enforcement denied, 296 F.2d 137 (6th Cir. 1961); Shea Chem. Corp., 121 N.L.R.B. 1027, 1029 (1958); William Penn Broadcasting Co., 93 N.L.R.B. $1104,1105,1106$ (1951).

5 See, e.g., Cone Mills Corp., 110 N.L.R.B. 830, 833 (1954); Advance Pattern Co., 80 N.L.R.B. 29 (1948). This usage was granted statutory recognition when section 8(b)(7)(A) was added to the act in 1959,73 Stat. 519.

G Ibid.

7 Shea Chem. Corp., 121 N.L.R.B. 1027, 1029 (1958); Radio Corp. of America, 74 N.L.R.B. 1729, 1731 (1947); Midwest Piping \& Supply Co., 63 N.L.R.B. 1060, 1070 (1945).

8 Signal Oil \& Gas Co., 131 N.L.R.B. 1427 (1961), enforced, 303 F.2d 785 (5th Cir. 1962); Buitoni Foods Corp., 126 N.L.R.B. 767 (1960); St. Louis Independent Packing Co., 129 N.L.R.B. 622, 629 (1960), enforced, 291 F.2d 700 (7th Cir. 1961); Shea Chem. Corp., supra note 7, at 1029; William Penn Broadcasting Co., 93 N.L.R.B. 1104-06 (1951); General Elec. X-Ray Corp., 67 N.L.R.B. 997 (1946).

9 Iowa Beef Packers, Inc., 144 N.L.R.B. No. 64, 54 L.R.R.M. 1109 (1963); Tri-W Construction Co., 139 N.L.R.B. 1286 (1962); Twin County Transit Mix Inc., 137 N.L.R.B. 1708 (1962); Signal Oil \& Gas Co., supra note 8; Brittany Dyeing and Printing Corṕ., 126 N.L.R.B. 785 (1960); Novak Logging Co., 119 N.L.R.B. 1573 (1958); Indianapolis Newspapers Inc., 103 N.L.R.B. 1750 (1953), enforcement denied, 210 F.2d 501 (7th Cir. 1954); International Harvester Co., 87 N.L.R.B. 1123 (1949); Flotill Prods., Inc., 70 N.L.R.B. 119 (1946). From 1954 until 1958 the Board did not apply the Midwest Piping doctrine to agreements signed with incumbent unions regardless of the existence of a question concerning representation. This exception, enunciated in William D. Gibson Co., 110 N.L.R.B. 660 (1954), was overruled in Shea Chem. Corp., 121 N.L.R.B. 1027 (1958).

In Ensher, Alexander \& Barsoom, Inc., 74 N.L.R.B. 1443 (1947), while election ob- 
found to exist. It has held that unless a question concerning representation exists the doctrine is inapplicable.10

The Board has not sought to justify its decision to make the doctrine coextensive with the existence of a question concerning representation. Such an approach does, however, simplify the Board's task in deciding whether or not to apply the doctrine. ${ }^{11}$ Moreover, the policy is consistent with the Board's view that the purpose of the doctrine is to protect employee choice by protecting the integrity of the Board's election processes.12 Thus, the Midwest Piping doctrine is applied where, but only where, a Board election is appropriate.

The courts have accepted the Board's verbal formulation of the doctrine in terms of the existence of a question concerning representation ${ }^{13}$ but have generally used the term "question concerning representation" to signify a situation in which the employer is ignorant of the wishes

jections made by the winning union were "technically ... still pending before the Board," the losing union became defunct. Id. at 1445. The Board declined to apply the Midwest Piping doctrine. It pointed out that this was not a case involving rival claims since at the time of recognition the recognized union was "the only labor organization claiming to represent [the] employees." Id. at 1444.

10 Downtown Bakery Corp., 139 N.L.R.B. 1352 (1962); Buitoni Foods Corp., 126 N.L.R.B. 767 (1960); Deluxe Metal Furniture Co., 121 N.L.R.B. 995 (1958); William Penn Broadcasting Co., 93 N.L.R.B. 1104 (1951); Lift Trucks, Inc., 75 N.L.R.B. 998 (1948).

In Pittsburgh Valve Co., 114 N.L.R.B. 193 (1955), enforcement denied on other grounds sub nom. District 50, UMW v. NLRB, 235 F.2d 565 (4th Cir. 1956), and Sunbeam Corp., 99 N.L.R.B. 546 (1952), the Board applied the Midwest Piping doctrine despite the absence of a statutory question concerning representation. The Sunbeam case was overruled sub silentio in Buitoni Foods Corp., supra. In Pittsburgh Valve Co., the charging union's petition was dismissed due to the fact that the bargaining unit was expanding. A Board election would have been available as soon as the expansion was complete. Thus the policy of applying the Midwest Piping doctrine where a Board election is immediately available was applicable despite the absence of a question concerning representation. The Pittsburgh Valve case might well be decided the same way today by the Board, although the Board's language in subsequent cases has strongly reaffirmed the identity of the doctrine with the existence of a statutory question concerning representation. Buitoni Foods Corp., 126 N.L.R.B. 767 (1960); Shea Chem. Corp., 121 N.L.R.B. 1027, 1029 (1958).

11 Thus, for example, in Swift \& Co., 128 N.L.R.B. 732 (1960), enforcement denied, 294 F.2d 285 (3d Cir. 1961), the Board rejected a series of complex arguments against application of the doctrine by pointing out that "the timely filing of a petition supported by an administratively determined showing of interest in fact raises a real question concerning representation." 128 N.L.R.B. at 736.

12 National Container Corp., 103 N.L.R.B. 1544 (1953), enforced, 211 F.2d 525 (2d Cir. 1954); International Harvester Co., 87 N.L.R.B. 1123 (1949); Flotill Prods., Inc., 70 N.L.R.B. 119, 121 (1946); NLRB, TENTH ANNUAL REPORT 38-39 (1946).

13 NLRB v. Swift and Company, 294 F.2d 285, 286-87 (3d Cir. 1961); NLRB v. North Elec. Co., 296 F.2d 137, 139-40 (6th Cir. 1961); Gleaver-Brooks Mfg. Corp. v. NLRB, 264 F.2d 637, 642 (7th Cir.), cert. denied, 361 U.S. 817 (1959); NLRB v. National Container Co., 211 F.2d 525, 536 (2d Cir. 1954). 
of his employees.14 As a result many Board decisions applying the doctrine have been reversed ${ }^{15}$ when brought to the courts for enforcement.

In representation proceedings a question concerning representation is raised by the filing of a petition if it has not been raised earlier by a demand for recognition. ${ }^{16}$ But in Midwest Piping cases the courts have rejected this criterion for the existence of a question concerning representation. Thus in St. Louis Independent Packing Co. v. NLRB (one of the few cases enforcing a Board Midwest Piping order) the court rejected the Board's conclusion that a real question of representation had arisen when the challenging union, in support of its claim for bargaining status, filed a representation petition with the Board. The

14 Thus in NLRB v. Swift \& Co., supra note 13, at 287, the Third Circuit stated that application of the Midwest Piping doctrine required "a finding of a real question of representation, i.e., that the employer had a reasonable basis for believing that the union no longer represented a majority." See also NLRB v. North Elec. Co., supra note 13, at 140; St. Louis Independent Packing Co. v. NLRB, 291 F.2d 700, 704 (7th Cir. 1961); Cleaver-Brooks Mfg. Co. v. NLRB, supra note 13, at 642; District 50, UMW v. NLRB, 234 F.2d 565, 569 (4th Cir. 1956). NLRB v. National Container Corp., 211 F.2d 525 (2d Cir. 1954), is the only case I know of in which the court adopted the Board's definition of a question concerning representation.

In NLRB v. Signal Oil and Gas Co., 303 F.2d 785 (5th Cir. 1962), the court's definition of question concerning representation required that the wishes of the employees be uncertain, but the court held on the basis of International Ladies Garment Workers v. NLRB, 266 U.S. 731 (1961), that even if the employer did not know of the rival union's claim at the time he granted recognition, he committed an unfair labor practice by continuing recognition of an incumbent at a time when employee choice was uncertain. This is contrary to the Board's position. The Board has indicated quite clearly that the employer must know of the rival claim in order for the Midwest Piping doctrine to apply. This generally presents no problem where a petition is filed since the employer is notified almost immediately. Where no petition is filed there must be a demand fọr recognition based on a substantial claim or else no question concerning representation is raised either for representation or Midwest Piping purposes. Downtown Bakery Corp., 139 N.L.R.B. 1352 (1962); Deluxe Metal Furniture Co., 121 N.L.R.B. 995 (1958); Siler Mill Co., 92 N.L.R.B. 1680 (1951). I believe the Fifth Circuit's opinion in the Signal Oil case misapplies the Supreme Court's Garment Workers decision. It would in practice require that an employer cease bargaining with a union on the basis of a naked claim by another. The reasons why this is undesirable are set forth in the Board's opinions in General Elec. X-Ray Corp., 67 N.L.R.B. 997 (1946), and Deluxe Metal Furniture Co., supra.

15 NLRB v. North Electric Co., 296 F.2d 137 (6th Cir. 1961); NLRB v. Swift \& Co., 294 F.2d 285 (3d Cir. 1961); NLRB v. Wheland Co., 271 F.2d 122 (6th Cir. 1959); CleaverBrooks Mfg. Corp. v. NLRB, 264 F.2d 637 (7th Cir. 1959); cert. denied, 361 U.S. 817 (1959); District 50, UMW v. NLRB, 234 F.2d 565 (4th Cir. 1956); NLRB v. Indianapolis Newspapers, Inc., 210 F.2d 501 (7th Cir. 1954); Stewart Warner Corp. v. NLRB, 194 F.2d 207 (4th Cir. 1952); NLRB v. Standard Steel Spring Co., 180 F.2d 942 (6th Cir. 1950). In only three Midwest Piping cases was the Board's order enforced. NLRB v. Signal Oil \&: Gas Co., supra note 14; St. Louis Independent Packing Co. v. NLRB, 291 F.2d 700 (7th Cir. 1961); NLRB v. National Container Corp., supra note 14.

16 See, e.g., Casey-Metcalf Mach. Co., 114 N.L.R.B. 1520 (1955); Calcasieu Paper Co., 109 N.L.R.B. 1186 (1954); Wiley Mfg. Co., 92 N.L.R.B. 40 (1950); Advance Pattern Co., 80 N.L.R.B. 29 (1948); I. Spiewak \& Sons, 71 N.L.R.B. 770, 771 (1946). 
court stated: "The record before us discloses nothing to make petitioner aware that a 'real question' of representation existed until the Board ordered an election. The fact that Amalgamated petitioned for representation does not in and of itself raise a real question of representation. It merely shows that Amalgamated asserted a claim to majority representation."17 The court concluded instead that a real question of representation arose when the Board ordered an election. ${ }^{18}$ This test has apparently been accepted in subsequent judicial decisions. ${ }^{19}$

Similarly, under the Board's definition, the question of representation is not resolved until a Board election is held and the results certified.20 But the courts take the view that the question of representation is resolved and the Midwest Piping doctrine becomes inapplicable when there has been an expression of majority support for one of the unions. ${ }^{21}$

17291 F.2d 700, 704 (7th Cir. 1961).

18 rbid.

19 NLRB v. North Elec. Co., 296 F.2d 137, 139-40 (6th Gir. 1961); NLRB v. Swift \&. Co., 294 F.2d 285, 288 (3d Cir. 1961). Using the Board's order of election as the standard is inconsistent with the courts' own definition of a question concerning representation. The order of election tells the employer nothing concerning the strength of the petitioning union's claim for recognition. The Board requires that a union support an election petition with a showing of interest by thirty per cent of the employees in the unit claimed to be appropriate. $\S 101.18$ N.L.R.B. Statements of Procedure, ser. 8 (1959).

An example of the incongruous results which may be achieved by the use of this test is offered by a comparison of NLRB v. Swift \& Co., supra, with St. Louis Independent Packing Co. v. NLRB, 291 F.2d 700 (7th Cir. 1961). Both cases involved the same employer, Swift \& Co., the same unions, and the same master bargaining negotiations. The agreements negotiated by the employer and the incumbent were to be applied to both the Harrisburg plant involved in the Swift of Co. case and the St. Louis plant. The challenging union filed petitions for election at both plants and made the necessary thirty per cent showing of interest with respect to both plants. An election had been ordered at the St. Louis plant but had not yet been ordered at the Harrisburg plant when the negotiations were completed. There was nothing in the record to suggest that the company had any more reason to suspect that the incumbent union no longer represented a majority at the St. Louis plant than it had to suspect the same with respect to the Harrisburg plant. As far as the possible coercive effect on the employees' choice of bargaining representative was concerned there was similarly no basis for distinguishing between the two cases. The courts, according to the opinions, shared the same definition of a question concerning representation, yet on the bases of the Board's order of election the Board's decision was enforced in the St. Louis Independent Packing Co. case, but denied enforcement in the Swift \& Co. case.

20 Iowa Beef Packers, Inc., 144 N.L.R.B. No. 64, 54 L.R.R.M. 1109 (1963); Twin County Transit Mix, Inc., 137 N.L.R.B. 1708 (1962); The Wheland Co., 120 N.L.R.B. 814 (1958), enforcement denied, 271 F.2d 122 (6th Cir. 1959); Indianapolis Newspapers Inc., 103 N.L.R.B. 1750 (1953), enforcement denied, 210 F.2d 501 (7th Cir. 1954); Radio Corp. of America, 74 N.L.R.B. 1729 (1947).

21 NLRB v. Wheland Co., 271 F.2d 122 (6th Cir. 1959); Cleaver-Brooks Mfg. Corp. v. NLRB, 264 F.2d 637 (7th Gir. 1959); District 50, UMW v. NLRB, 234 F.2d 565 (4th Cir. 1956); NLRB v. Indianapolis Newspapers, Inc., $210 \mathrm{~F} .2 d 501$ (7th Cir. 1954); NLRB v. Standard Steel Spring Co., 180 F.2d 942 (6th Cir. 1950). 
This difference in definition between the Board and the courts stems from differing views as to the function of the Midwest Piping doctrine. As noted above, the Board views the doctrine in part as a way of insuring the integrity of its election machinery. It thus holds the doctrine applicable whenever an election is appropriate, and the Board will go ahead with an election despite a prior expression of majority sentiment.

The courts on the other hand have thought of the Midwest Piping doctrine solely as a technique for preventing the employer from imposing his own choice of a bargaining representative upon his employees. This was best articulated by the Seventh Circuit in NRLB v. Indianapolis Newspapers, Inc.:

The act forbids interference by an employer with the rights of his employees to bargain collectively, and, for that purpose, to select their own bargaining representative. When two unions are vieing [sic] for majority support of his employees, an employer must, of course, maintain a position of strict neutrality . . . . Recognition of one competitor as bargaining agent during this contest period, absent proof of majority support, is a proscribed act....

The Act does not require, however, that this neutrality continue until the last dissident voice is stilled. Indeed, in keeping with the purpose of the Act, harmonious employer-employee relations require that the instability inherent in a contest end when one contestant is able to muster majority support. Although the prize of recognition must not be employed coercively to influence the employees in making their decision, once indisputable proof of majority choice is presented to the employer, the Act imposes on him a duty to award recognition to the agent so chosen by his employees. ${ }^{22}$

Under this view a statutory question concerning representation may exist without the Midwest Piping doctrine's being applicable.

The courts have probably been willing to accept formulation of the doctrine in terms of the existence of a question concerning representation because, when the term is given a literal rather than a statutory meaning, it is descriptive of the courts' approach to the doctrine. But the results of the appearance of agreement have been unfortunate. Judicial review has been undertaken without recognition of the real basis of the Board's decision. Thus the Third Circuit in NLRB v. Swift ir Co. purports to apply a substantial evidence test to the Board's "finding . . . that the employer had a reasonable basis for believing that the union no longer

$22210 \mathrm{~F} .2 \mathrm{~d}$ at 503,504 . The Board specifically declined to follow this decision in Novak Logging Co., 119 N.L.R.B. 1573 (1958). 
represented a majority." 23 The Board made no such finding. It based application of the doctrine on "the timely filing of the petition supported by an administratively determined showing of interest . . . ."24

In addition, because none of the judicial decisions in the area appear to challenge the doctrine directly, the Board has not felt the need to elaborate or justify its approach to the doctrine.

The desideratum of clarity suggests that a term which is already a term of art in the representation area not be given a different meaning for purposes of the Midwest Piping doctrine. Accordingly, the courts should use the term "question concerning representation" in Midwest Piping cases in its statutory sense as it is used by the Board. Hopefully, the courts and the Board would in turn be forced to challenge' the assumption that the scope of the doctrine and the scope of the term are coextensive; and the challenge to that assumption might lead to a long overdue reevaluation of the doctrine by the Board.

The difficulties in the Midwest Piping doctrine are highlighted by its use in two different but overlapping classes of situations: Where there is negotiation of an agreement with an incumbent union when a rival union is seeking to represent the unit and where there has been an expression of majority sentiment after the question concerning representation arises. In both situations, the policy of the Board and of the courts has been shaped by an assumption which must be evaluated: That recognition is inherently coercive.

\section{Application of the Midwest Piping Doctrine to Negotiation of an Agreement With an INGUMbent Union}

In 1954 in William D. Gibson Co. ${ }^{25}$ the Board created an exception to the Midwest Piping doctrine to meet the case where an employer contracted with an incumbent union: A contract negotiated by the employer and an incumbent would not bar an election, but negotiation of the contract did not constitute an unfair labor practice as unlawful interference with the employees free choice of bargaining representative. ${ }^{26}$ The exception was justified on the grounds that "stability in industrial relations, the primary objective of the Act, requires that continuity in collective-bargaining agreements be encouraged, even though a rival union is seeking to displace an incumbent." 27 This exception

23294 F.2d 285, 287 (3d Cir. 1961). See also NLRB v. North Elec. Co., 296 F.2d 137, 140 (6th Cir. 1961), and see Note, 111 U. PA. L. Rev. 930, 948-49 (1963).

24128 N.L.R.B. 732,736 (1960).

25110 N.L.R.B. 660 (1954).

26 Id. at 662 .

27 Ibid. 
was overruled without discussion in Shea Chem. Corp. ${ }^{28}$ The closest the Board has ever come to an explanation of this action was when it adopted the language of the Trial Examiner in the St. Louis Independent Packing Co. case. "The situation is no different where one of the competing unions has been the incumbent bargaining representative of the employees involved. The right of employees to change their bargaining representative carries no less dignity in the statutory scheme than their right to choose in the first instance between unions competing for representative status." 20

On petition for review, the Seventh Circuit similarly concluded that "The fact that NBPW was the incumbent union and had been certified some five years earlier did not exempt petitioner from its duty of neutrality once a real question of representation arose."30

The assertion that "the right of employees to change their bargaining representative carries no less dignity in the statutory scheme than their right to choose in the first instance," is persuasive so long as it is assumed that the possible coercive effect of recognition is the same regardless of whether an outside or an incumbent union is involved. ${ }^{31}$ But such an assumption would be inaccurate.

Where an incumbent union is involved, whatever aura of responsibility may otherwise attach to recognition has already been acquired through the previous history of representation. It cannot be erased by a short suspension of recognition, particularly since the Board in Shea Chem. Corp. specifically stated that the employer may permit the incumbent union to continue administering its contract or processing grievances through its stewards. ${ }^{32}$

Further, it appears unlikely that employees would view the continuation of dealings with an incumbent as an expression of choice to the same extent that they would view recognition of one of two outside unions as such an expression. I doubt that employees concern themselves with the motives leading to continued dealings. People tend to notice and to seek to explain new modes of behavior; customary forms are accepted. Moreover, to the extent that customary behavior is noted, it is more

28 The Board's entire discussion of the point was as follows: “[A]fter full consideration of all the implications of the Gibson exception we have decided to overrule that case." 121 N.L.R.B. 1027, 1029 (1958).

29129 N.L.R.B. 622,629 (1960).

30 St. Louis Independent Packing Co. v. NLRB, 291 F.2d 700, 704 (7th Cir. 1961).

31 If it were merely a question of balancing the interests of industrial stability and free choice by employees such balancing would seem to fall within the Board's area of discretion. The Board grants considerable protection to industrial stability through such devices as its contract bar and certification year rules. $C f$. Deluxe Metal Furniture Co., 121 N.L.R.B. 995 (1958).

32121 N.L.R.B. 1027,1029 (1958). 
likely to be attributed to habit than to choice. New types of behavior are more likely to be construed as an indication of choice and properly so. Indeed, withdrawal of recognition may well be viewed as a rejection of the incumbent union and not as an act of neutrality. ${ }^{33}$

It is, of course, almost always true that the employer has demonstrated his willingness to deal with the incumbent union but not with its rival. However, this demonstration was made before the question concerning representation arose, probably before the rival arrived on the scene. This is part of the status of incumbency which cannot be erased by the withdrawal of recognition contemplated by the Board. Any advantage which accrues in this situation does not appear to be unfair. I think its practical effect can be sufficiently neutralized if the employer, as was done in the Swift cases, ${ }^{34}$ makes a clear statement of his willingness to deal with whatever union the employees choose. The fact that the incumbent was able to establish bargaining relations with the employer is likely to be taken as proof that the employer will abide by his word.

Negotiation of an agreement with an incumbent union, like negotiation of an agreement with an outside union, provides tangible benefits which the employees may be tempted to vote to retain. The impact of this factor on an election is hard to gauge. The effect of a desire to retain benefits must be balanced against the force of the attitude that the employer could not go below but might be forced to go beyond his previous concession if a new union were selected. I do not believe that the possibility of coercion on this account is sufficient to overcome the disruptive effects of discontinuing collective bargaining pending an election.

In reaching this conclusion $I$ am in part persuaded by the severe consequences likely to follow the finding of a violation. With the exception of the North Elec. Co. ${ }^{35}$ case, the Board has uniformly required that the employer withdraw recognition from the union previously recognized and cease giving effect to the previously negotiated contract. The withdrawal of recognition is to last until the previously recognized union "shall have demonstrated exclusive majority representative status pursuant to a Board-conducted election." 36

33 I thought of suggesting that this problem be resolved by social science research into employee attitudes. However, this would make an extremely difficult problem in attitude research. It would not be surprising if different experiments pointed in different directions. Rules of conduct legally enforced require more solid grounding in order to provide a minimum degree of consistency.

34 St. Louis Independent Packing Co. v. NLRB, 291 F.2d 700 (7th Cir. 1961); NLRB v. Swift \& Co., 294 F.2d 285 (3d Cir. 1961); see note 19, supra.

35129 N.L.R.B. 675 (1960), enforcement denied, NLRB v. North Elec. Co., 296 F.2d 137 (6th Cir. 1961).

36 St. Louis Independent Packing Co., 129 N.L.R.B. 622 (1960); see also Douglas Canning Co. Inc., 85 N.L.R.B. 1005 (1949). The order to withdraw recognition customary in $\S 8(\mathrm{a})(2)$ cases is called a "Resnick remedy." See Julius Resnick Inc., 86 N.L.R.B. 38 
There is thus a hiatus period established by the Board order. Bargaining is suspended first until the effects of the unfair labor practice have been "dissipated" and then until an election is held and the results certified. Moreover, the hiatus period may coincide with the termination of a collective bargaining agreement. In that case the employees will be denied the possibility of having new wage rates or other improvements in their working conditions negotiated for them until the period ends and an election is held. The cure seems more drastic than the violation and more likely to hinder the effectuation of free employee choice.

\section{Application of the Midwest Piping Doctrine to Cases in Which There Has Been an Expression of Majority Sentiment After the Question Concerning Representation Arose}

In the Midwest Piping case the employer sought to justify negotiation of an agreement with one of the rival unions on the grounds that it had obtained signed authorization cards from a majority of his employees. The Board rejected the use of the cards as proof of a majority:

Under the circumstances, we do not regard such proof as conclusive. Among other things, it is well known that membership cards obtained during the heat of rival organizing campaigns like those of the respondent's plants, do not necessarily reflect the ultimate choice of a bargaining representative; indeed, the extent of dual membership among the employees during periods of intense organizing activity is an important unknown factor affecting a determination of majority status, which can best be resolved by a secret ballot among the employees. ${ }^{37}$

(1949). In the North Electric case the Board for the first time applied the Midwest Piping doctrine but did not apply the Resnick remedy. The union in that case had not filed objections to the election based on the conduct found to violate the Midwest Piping doctrine. The Board concluded that "Even though the Respondent violated Section 8(a)(1) of the Act, a remedy for this violation that resulted in setting aside the contract and invalidating the certification of the ... [union] would permit the Charging Union to accomplish indirectly through the filing of an unfair labor practice charge what it could not accomplish directly by filing objections to the election." 129 N.L.R.B. at 676-77. See F. W. Woolworth Co., 109 N.L.R.B. 1446 (1954), modified by Ideal Elec. \&: Co., 134 N.L.R.B. 1275 (1961); Goodyear Tire \&. Rubber Co., 138 N.L.R.B. 453 (1963). Instead the Board ordered respondent to "cease and desist" from engaging in such conduct-in effect not to do it again. Thus a union which chooses to go to an election rather than object to pre-election order conduct can file charges but cannot obtain the benefits of a Resnick remedy. So long as the Board follows the practice established in the North Electric case, it is unlikely that the losing union will file charges in such cases. Even if charges were filed the results would be essentially meaningless. Thus the effect of the North Electric case will likely be to remove certain cases from the practical scope of the Midwest Piping doctrine rather than to mitigate the harshness of the remedy applied where Midwest Piping violations are found. Conduct after the order of election, but prior to the election can sustain a Resnick remedy. St. Louis Independent Packing Co., supra, at 630.

3763 N.L.R.B. 1060, 1070 (1945). 
The Board has applied this language to all other cases in which the employer has sought to demonstrate through signed authorization cards that the union recognized represented a majority of employees. ${ }^{38}$ As the doctrine became more and more identified with the existence of a statutory question concerning representation, it became a rigid rule that a company could not "assume to judge for itself upon a showing of authorization cards which of the contending unions was the statutory representative of the employees." 39 This approach was carried over to cases in which other forms of proof of majority were attempted.40 The Seventh Circuit was accurate in stating that "the Board's position is that nothing short of the results of a secret ballot is a reliable criterion for recognition of a bargaining agent when two unions are competing for the employee's support." 41

Conceding that authorization cards are frequently unreliable, the Board's approach is difficult to justify on grounds other than the technical existence of a question concerning representation. For one thing, cards may be a reliable index of sentiment in some cases, and the Board makes no effort to analyze their reliability on a case by case basis. Nor has the Board offered any justification for application of the Midwest Piping doctrine in cases in which other forms of majority proof have been offered.

The Board's approach to recognition before an election in rival union cases is in marked contrast to its approach when only a single union is involved. In the latter situation, even if a question concerning representation has been raised, the employer is required to recognize a union which establishes its majority in advance of an election. And authorization cards may constitute sufficient proof to require recognition. ${ }^{42}$ It is only where affirmative proof of minority status is available that the

38 Iowa Beef Packers, Inc., I44 N.L.R.B. No. 64, 54 L.R.R.M. 1109 (1963); Novak Logging Co., 119 N.L.R.B. 1573 (1958); The Wheland Co., 120 N.L.R.B. 814 (1958); Radio Corp. of America, 74 N.L.R.B. 1729 (1947).

39 Novak Logging Co., supra note 38, at 1575.

40 Cleaver-Brooks Mfg. Corp., 264 F.2d 637 (7th Cir. 1959); Twin County Transit Mix Inc., 137 N.L.R.B. 1708 (1962); Indianapolis Newspapers, Inc., 103 N.L.R.B. 1750 (1953).

41 NLRB v. Indianapolis Nerwspapers, Inc., 210 F.2d 501, 503 (7th Cir. 1954). See also NLRB, TENTH ANNUAL REPORT 39 (1946). Whether there is any situation short of that existing in the Ensher case, 74 N.L.R.B. 1443 (1947), in which the employer would be justified, in the Board's view, in recognizing a union without awaiting an election is not clear. It is clear that even reliable proof of majority is not enough. See Iowa Beef Packers, Inc., 144 N.L.R.B. No. 64, 54 L.R.R.M. 1109 (1963); Twin County Transit Mix Inc., 137 N.L.R.B. 1708 (1962).

42 Robert P. Scott, 134 N.L.R.B. 1120 (1961); Bilinski Sausage Mfg. Co., 132 N.L.R.B. 229 (1961). 
Board has held recognition in advance of election to be an unfair labor practice. ${ }^{3}$

In its Midwest Piping opinions the Board uses language which suggests that under the act its election machinery has some special pertinence to situations involving rival claims for recognition. In the Novak Logging Co. case, for example, despite the fact that no petition for an election was filed, the Board stated: "As reasonably contemplated by the statute the determination of the existing question concerning representation was exclusively one for the Board." 44 But the language of the act no more requires an election as the exclusive mode for the settlement of questions of representation when rival claims exist than it does when a single union seeks recognition. The distinction is a product of Board decisions with no effort made to explain the disparity of treatment between the two classes of cases. It is not easy to explain why, in a single union situation, recognition on the basis of authorization cards is required while, when rival claims are involved, it is proscribed.

When the decision facing the employees is whether or not they desire union representation, recognition may have a greater impact than it does when the choice is between rival unions. Employees previously opposed to or afraid of unionism may discover that their fears were groundless or that the union has obtained more benefits for them than they had thought that it could. A union once recognized, or once agreement has been reached, may appear less radical and more responsible than it did earlier. I would suggest that such a reaction is more likely on the part of employees previously opposed to any union than it is on the part of the adherents of one union when another is recognized. Further, the interest involved in the single union case, in being able to freely select not to be represented, seems at least as significant as the interest in the free choice between unions.

It is probably true that authorization cards are less reliable where rival unions seek recognition than they are normally. It is more likely that a union man will sign two authorization cards than that an anti-union man will sign one. But the problem of dual authorization can be dealt with effectively if the employer takes the trouble to compare the authori-

43 Bernhard-Altmann Texas Corp., 122 N.L.R.B. 1289 (1959), aff'd sub nom. International Ladies Garment Workers' Union, AFL-CIO v. NLRB, 366 U.S. 731 (1961). The Supreme Court in upholding the Board's finding of a violation in this case stated that the employer could have protected himself by checking authorization cards to ascertain the wishes of his employees. Id. at 739-40.

44 Novak Logging Co., 119 N.L.R.B. 1573, 1575 (1958). (Emphasis added.) See also Iowa Beef Packers, Inc., 144 N.L.R.B. No. 64, 54 L.R.R.M. 1109 (1963); Swift \& Co., 128 N.L.R.B. 732, 736 (1960); William D. Gibson Co., 110 N.L.R.B. 660, 662 (1954); Midwest Piping \& Supply Co., 63 N.L.R.B. 1060, 1070 (1945); NL.RB, TENTH ANNUAL REPORT 39 (1946). 
zation cards obtained by the rival unions. In this way the extent of dual authorization can be determined together with the relative strength of the rival claims.

Another possible distinction is that employees are likely to view the employer's act of recognition as an indication of choice where rival unions are concerned but as a matter of compulsion when a single claim for recognition is granted. As is discussed more fully below, I question the assumption that such a perception by employees will lead them to vote in accordance with what they take to be the employer's wishes. Pretermitting that question, if the employer announces in advance that he will grant recognition on the basis of some objective criterion such as authorization cards, he should be able to act without having his conduct viewed as an expression of preference.

Similarly, it has been argued that to permit an employer to grant recognition on the basis of a manifestation of majority support enables him to observe "the ebb and flow of fluctuating sentiment" and to make "timely recognition of the favored union." 45 Where the Board properly finds as a matter of fact that an employer has used this tactic, a finding of violation would be appropriate, and would likely be upheld by the courts. But I do not think this practice so widespread that the Board should infer its existence from the fact of recognition based on authorization cards or other proof of a majority. I also think it highly unlikely that the courts would accept such an inference if it were not supported by other evidence. When an employer can demonstrate that he was in fact neutral or that he acted on the basis of some objective criterion selected in advance of recognition, this rationale is unavailable to support the Board's application of the doctrine.

There thus seems little support in terms of the interests of the employees involved for the distinction drawn by the Board between employers faced with a single claim and employers faced with more than one claim for recognition. The real basis for the distinction may be, however, that an election following recognition is likely where rival claims are involved but is highly unlikely where an employer recognizes the single union seeking recognition. In applying the Midwest Piping doctrine the Board is largely concerned with protecting the integrity of its election processes. If one assumes the coercive effect of recognition, then even where the union recognized represented a majority at the time

45 See Cleaver-Brooks Mfg. Corp. v. NLRB, 264 F.2d 637, 642 (7th Cir.), cert. denied, 361 U.S. 817 (1959). The Board itself has never sought to justify application of the Midwest Piping doctrine on this basis. It was put forward for the first time by Board counsel in the Cleaver-Brooks case. This tactic is open to an employer faced with a demand by a single union for recognition. But it is true that an employer is more likely to favor one union over another than to favor one over none. 
of recognition, the employer's conduct may substantially affect the Board's election machinery. The period remaining between the time of recognition and the election can no longer be effectively used to change the minds of the employees. A shift in sentiment based upon the election campaign is thereby precluded, and the election merely serves the purposes of ratifying the employer's previous act of recognition. ${ }^{46}$

I do not believe, however, that the likelihood of a Board election being held in the rival union situation justifies the conclusion that an employer may not therefore recognize a union reasonably and fairly ascertained to be the choice of a majority of his employees. I believe the Board overestimates the effect of recognition in such a situation and, moreover, that where recognition is withheld pending an election, the danger is outweighed by the considerable delay which may ensue before the employees' statutory right to bargain through representatives of their own choosing is effectuated. A minority union can delay the election by technical objection or an unfair labor practice charge. ${ }^{47}$ And if employers were compelled to withhold recognition pending an election, minority unions would be motivated to employ such tactics in order to gain campaigning time.

It is probably characteristic of bureaucratic enterprises that they give to their own procedures unwarranted significance. The Board should realize that its election process is only a means for determining employee choice. It should not be used as a basis for delaying effectuation of that choice.

\section{The Coercive Effect of Recognition}

The Midwest Piping doctrine rests ultimately on the assumption that recognition is a potent form of assistance to the recognized union. Both the Board and the courts have treated the truth of this assumption as too plain to require discussion. On the few occasions when the Board has sought to explain the Midwest Piping doctrine, it has started from the proposition that an employer infringes upon his employees freedom to select their own bargaining representative if he recognizes or contracts with a labor organization during the pendency of a question concerning representation. ${ }^{48}$ There is no suggestion in any opinion of the Board or

46 "To hold otherwise would be to sanction futile elections and invite abuse of our process." International Harvester Co., 87 N.L.R.B. 1123, 1127 (1949). See also TENTH ANNUAL REPORT, op. cit. supra note 44.

47 The Board has a uniform policy of not proceeding with representation matters while there are unwaived unfair labor practices charges pending before it. Surprenant Mfg. Co. v. Alpert, 53 L.R.R.M. 2405 (1963); cf. NLRB v. Trimfit of California, Inc., 21 I F.2d 206, 209 (9th Cir. 1954); NLRB v. Electronics Equip. Co., 194 F.2d 650, 651 (2d Cir. 1952).

48 International Harvester Co., 87 N.L.R.B. 1123, 1125 (1949); Radio Corp of 
any court opinion of which $\mathrm{I}$ am aware that this effect is not universally present.

Apparently this proposition rests upon two other assumptions: First, that recognition is perceived by the employees as an indication of the employer's choice between the claimants and, second, that the employees will be likely to vote in accordance with their perception of the employer's wishes. 49

The first assumption is often highly questionable. In fact recognition may not be an indication of choice. Thus in the Swift \& Co. and St. Louis Independent Packing cases the employer had a uniform practice of continuing to recognize the incumbent union, and in NLRB v. Indianapolis Newspapers, Inc. the employer at first refused to recognize the insurgent union upon the basis of petitions signed by more than fifty per cent of the employees. It is not clear in these cases why it is assumed that the employees will be misled into believing that recognition is an indication of choice. The election campaigns in the Swift and St. Louis Independent Packing cases would have made any employee aware that Swift had contractual relations on a multi-plant basis with three different meat packing unions.

The second assumption is even more questionable than the first. There are of course reasons why employees in particular cases might vote in accordance with their perception of the employer's wishes. They might, for example, feel that the employer knows better than they what is in their own best interest. Common observation indicates that this is not likely to be true very often. And, moreover, one might suppose that employees with such a high regard for the employer's wisdom and with such assurance of his solicitousness for their welfare would not vote for any union.

The employees might, of course, feel that a favored union will be able to deal with the employer more effectively. It is not altogther clear to me that a vote cast on the basis of such a consideration is "coerced." And while one can only speculate as to the prevalence of such an attitude,

America, 74 N.L.R.B. 1729, 1731 (1947); Midwest Piping \& Supply Co., 63 N.L.R.B. 1060,1070 (1945). In support of this conclusion the Board has relied upon language used by the U.S. Supreme Court in NLRB v. Pennsylvania Greyhound Lines, Inc., 303 U.S. 261, 267 (1938), to the effect that "once an employer has conferred recognition on a particular organization it has a marked advantage over any other in securing the adherence of employees. . . ." See Flotill Products Inc., 70 N.L.R.B. 119, 120 (1946). This language was used in a case in which the employer had "fostered," "dominated," and otherwise assisted the union recognized. The Supreme Court cited authority concerning the importance of recognition in a single union situation. This authority dated from 1933-1937.

49 St. Louis Independent Packing Co., 129 N.L.R.B. 622, 629 (1960) (by implication); Elastic Stop Nut Corp., 51 N.L.R.B. 694, 704 (1943) (by implication enforced). 
my own feeling is that employees are more likely to vote against a union thought to be favored by the employer on the assumption that it will not be aggressive enough in advancing their interests, than they are to vote in its favor because of any potential effectiveness in dealing with the employer. The term "company union" still has strong pejorative connotations, and disdain for the "teacher's pet" has deep roots in American society. 50

Employees may be motivated to vote as they think the employer wishes out of fear that he will not deal at all with the non-favored union and that he will engage in reprisals against its supporters. Where recognition helps to convey this impression, its effect is coercive. But I doubt that there are many such cases. And I think that in all of them recognition is accompanied by other acts of discrimination.

If the Board were to reappraise the Midwest Piping doctrine it might conclude that the assumption that recognition has a coercive effect made more sense in 1945 than it does now. In many cases in which the Midwest Piping doctrine has been applied the facts were inconsistent with such a theory of coercion. The Swift cases were of this type: The company announced authoritatively to the men that it would recognize whatever union they chose and its bargaining history of dealing with all unions would have made this clear after the most superficial examination. Surely the Board can expect this much sophistication on the part of the employees. 51 Moreover, an employer need not choose so indirect a way of

50 In Note, supra note 23 , at 932 , the writer comments "were the employer permitted to recognize one union, it could exert considerable pressure on its employees to choose that union as their bargaining agent although the unrecognized rival might be the better representative. Indeed the employer may have intended to recognize the union that would be less demanding." It may well be that employees will share the skepticism of the writer of the note concerning the employer's motives.

51 See, e.g., General Elec. Co., 110 N.L.R.B. 744 (1954); International Harvester Co., 87 N.L.R.B. 1123 (1949). In the latter case the employer signed a master agreement with the incumbent Farm Equipment Workers (FE) during the pendency of a petition at a particular plant by the challenging UAW. The new contract was applied to the plant in question. The company and the UAW had signed a master agreement with respect to the company's plants represented by UAW. The employer kept the employees informed of the state of negotiations by a series of letters. The election campaigns centered about the relative attractiveness of the two master agreements. The trial examiner found the Midwest Piping doctrine inapplicable, because of the absence of coercion. "It was abundantly clear to the employees that if they preferred the UAW to the FE all they had to do was vote for it in the election, and the UAW's national contract would automatically become applicable to them." Id. at 1139. The Board reversed the examiner. Its direct analysis of the coercion issue consisted of one sentence in the body of the opinion: "And, as we have pointed out many times, an employer's election to recognize and deal with a labor organization whose representative status is in question constitutes serious interference with his employees' freedom to make their own choice of a bargaining agency," $i d$. at 1126, and one footnote: "The Trial Examiner appeared to believe that the results of the election in the representation case were not affected by the acts of the Respondent complained of here. However, 
indicating his preference. He is permitted under the act to state openly his choice among the rivals. ${ }^{52}$ If the Midwest Piping doctrine is to be justified it must be established that recognition and negotiation of an agreement are more effective in influencing employee choice than a direct statement of preference by the employer.

It might be argued that the negotiation of an agreement puts pressure upon the employees to vote to retain the agreement and the union which negotiated it. In St. Louis Independent Packing Co. v. NLRB the brief for the Board stated: "In any subsequent election employees will be aware that voting for the incumbent union means retention of whatever practical benefits the union has achieved. There is no such assurance with respect to the rival union." 53 On the other hand the employees might assume that any agreement currently in force is the minimum that a new union would obtain. In fact, the company's refusal to offer to an incoming union the same terms negotiated with the union's predecessor might well appear to constitute a refusal to bargain in good faith.

The Board has referred to the "unwarranted prestige" which accrues to the recognized union. ${ }^{54} \mathrm{It}$ is not clear, exactly, what is meant by this term. To some extent the Board is doubtless relying on the assumption, discussed above, that recognition carries the mantle of employer approval

as we have uniformly held, the Board cannot base its findings of unfair labor practices on speculation as to whether or not the unlawful conduct was actually effective to influence the employees in a particular case. The proper test is whether or not such conduct tends to interfere with the free exercise by employees of their rights under the Act." Id. at $1126 \mathrm{n.8}$. It is remarkable to hold an employer guilty of a violation of the act because similar conduct in other cases is likely to be coercive. But this is what the use of the word "tends" implies. The Board does not appear to be talking about a tendency in the case before it which it would be difficult to illustrate with particular proof, for a finding of such a tendency involves "speculation as to whether or not the unlawful conduct was actually effective to influence the employees in a particular case."

52 See note 1 supra.

53 Brief for NLRB, pp. 26, 27, St. Louis Independent Packing Co. v. NLRB, 129 N.L.R.B. 622 (1960). To the extent that the Midwest Piping doctrine is based on this "bird in the hand" coercion it should not be applied to recognition apart from the negotiation of an agreement. The Board heretofore has not differentiated between the two. The language quoted from Novak Logging Co., text accompanying note 4 supra, is typical in its equation of recognition and the negotiation of an agreement.

Whatever the general validity of this theory of coercion, it would hardly seem applicable where, as in the Swift cases, the employer at all relevant times was in the process of negotiating master agreements with both unions. In fact the election campaign by the losing union was pitched largely in terms of the superiority of its forthcoming master agreement, the essential features of which were already established when the election was held. The election was fought on two issues: The incumbent's performance in the role of bargaining representative since 1954 and the relative advantages of the two master agreements.

54 Scherrer and Davisson Logging Co., 119 N.L.R.B. 1587, 1589 (1958); TENTH ANNUAL REPORT, op. cit. supra note 44. 
and choice. ${ }^{55}$ Beyond this, unwarranted prestige may be thought to accrue from the position of authority which the recognized union will occupy in the plant. Union leaders will be dealing with high management officials with respect to grievances and on the negotiation of an agreement. From these dealings the union will acquire an aura of responsibility which will give it an advantage over rivals in a forthcoming election. As noted above, this prestige factor, to the extent that it is in fact a factor, has already accrued to an incumbent union and is not likely to be erased by withdrawing recognition.

With respect to a newly recognized union the likely impact of the prestige factor is problematical. In many cases grievance machinery would not be set up prior to the election and the sole factor adding to the prestige of the union would be the fact that it is negotiating an agreement with the employer. I doubt that many votes will be swayed by this fact alone. Indeed, if there is a lengthy bargaining period, backers of the recognized union may well be disappointed by its inability to achieve quickly what it promised.

Where an agreement is negotiated and grievance machinery established, I would expect that many more employees would be influenced by their appraisal of the agreement, than would be influenced by the aura of responsibility stemming from the union's role in processing grievances. One may even doubt that newly established grievance machinery will run smoothly enough to cast an aura of responsibility over the participants. Employees have become accustomed to unions acting in positions of responsibility. It is not clear that they will be overly impressed with one more example of a common phenomenon. And in this regard I would suggest that recognition is more likely to affect the attitudes of employees previously opposed to any union, than it is to affect the adherents of one union when another has been recognized. In the typical Midwest Piping case, the vast majority of the employees are adherents of one or the other rival unions and only a few are opposed to any representation.

Implicit in this theory of coercion, and in all of the other theories discussed, is the assumption that employee choice is made on a totally unsophisticated basis, and can be easily manipulated. I doubt the validity of this assumption. Unless one accepts it, it is difficult, if not impossible, to find a theory which adequately supports the position that recognition necessarily coerces employees in choosing their bargaining representative.

My point is that the effect of recognition will vary in different circumstances. If $I$ am right, it raises the question of whether the Board should do away with the Midwest Piping doctrine and seek to determine from

55 See Note, supra note 23 , at 932. 
the facts of the case before it whether recognition or the negotiation of an agreement interfered with free choice by the employees.

The argument against abandoning the doctrine is that such a move would replace certainty with confusion. It would make it difficult, if not impossible, for employers to know in advance whether they might lawfully grant recognition to one of the rivals. And it would force the Board to spend considerable time pouring over the records of cases in order to make delicate factual judgments, the validity of which would in any case be doubtful. The Board faced with a rapidly mounting case load cannot afford the time which would be necessary for such a case by case evaluation. Moreover, the Midwest Piping doctrine, like all doctrines, minimizes the amount of discretion involved in decision making. It insures that the Board will not decide cases involving the interests of rival unions on a partisan basis. Perhaps, more importantly, it helps insure that Board decisions will be viewed by the parties as the result of the application of neutral principles to the facts, and not as the result of caprice or bias.

However, the position of employers who seek to obey the law would not be worsened if the Midwest Piping doctrine were abandoned, for such employers could still protect themselves by withholding recognition pending a Board election. The temptation to do so would be great, especially since recognition of a union later determined to be a minority union automatically constitutes a violation of the act. ${ }^{56}$ Abandonment of the doctrine would mean only that the possibility of lawfully granting recognition would be available if it appeared from the facts that the effect of such recognition would not be coercive.

Nor is it clear that abandonment would increase the Board's work load. The non-recognized union faced with the possibility of the Board's upholding the employer's grant of recognition to its rival, might prefer to go ahead with an election rather than file charges or raise objections based on the grant of recognition. If the decision to go to an election were made, it might well be that charges would not be filed after the election, since under the Board's North Elec. Co. decision an unfair labor practice finding in such case might not lead to an order to withdraw recognition. ${ }^{57}$

While it is true that the Midwest Piping doctrine largely eliminates the possibility of partisanship by the Board, I have tried to show that it does so only at a high cost. The Board has the responsibility of bringing its expert judgment to bear on the individual case before it. It is an evasion of that responsibility for the Board to treat recognition as though its effect were always the same. And there is no reason why the Board could

56 See International Ladies Garment Workers' Union, AFL-CIO v. NLRB, 366 U.S. 731 (1961).

$5 \bar{r}$ See note 36 supra. 
not develop appropriate judicial standards by which to appraise the likely effect of recognition on a case by case basis.

In many ways the Midwest Piping doctrine is disruptive of smooth industrial relations. Employers and unions seeking to abide by the Board's rules have been required to interrupt or postpone bargaining relationships. Where the doctrine is applied there is a hiatus period in collective bargaining despite the fact that the majority of employees desire representation of one sort or another.

\section{ConcLusion}

The Midwest Piping doctrine is based on the assumption that the effect of recognition is necessarily coercive. This assumption is often erroneous and therefore the Board should discontinue its practice of automatically finding a violation whenever recognition and the existence of a statutory question concerning representation occur together. It should instead seek to determine the likely effect of recognition in the individual case before it. Where the employer's alleged violation consists of continued dealings with an incumbent union the assumption of coercion is particularly questionable. In the situation where one union has fairly demonstrated its majority status recognition should not be treated as a violation. A finding of violation in such a case only serves to promote the importance of the Board's election machinery at the expense of the employee's freely expressed choice. As such it gives undue importance to the Board's own procedures. 